\title{
Konsep Diri, Kematangan Emosi, dan Perilaku Bullying pada Remaja
}

\author{
Nurul Aulina ${ }^{1}$ \\ Fakultas Psikologi, Universitas Muhammadiyah Malang \\ email: ${ }^{1}$ nurulaulina09@gmail.com
}

\begin{abstract}
Bullying behavior is an act of violence committed to harm other people. Bullying behavior can be reduced or controlled by the existence of positive psychological variables, namely self-concept and emotional maturity. The aim of the study is to know, dig, review and organize theoretical and empirical information about self-concept relationships, emotional maturity with bullying behaviour in adolescents. Self-concept, emotional maturity, and bullying behavior studied in 150 early adolescents with an age range of 12-15 years. This research is a quantitative study with a partial correlation design and sampling techniques used is the sampling of quotas. The results showed no relation between self-concept and bullying behavior when the maturity of emotions was controlled ( $r=-0.040 ; p$ $=0.625$ ).
\end{abstract}

KEYWORDS Adolescence, behavior, bullying, emotional maturity, self concept

CITATION Aulina, Nurul. (2019). Konsep diri, kematangan emosi, dan perilaku bullying pada remaja, Cognicia, 7, (4), 434-445.

Kekerasan merupakan suatu hal yang tidak asing lagi terjadi di masyarakat. Secara umum, kekerasan dapat diartikan sebagai tindakan yang dapat menyebabkan keadaaan perasaan ataupun fisik seseorang menjadi tidak nyaman. Dalam psikologi, kekerasan diartikan sebagai tindakan agresi, yakni tindakan yang menyakiti orang lain. Akhir-akhir ini, kasus kekerasan yang terjadi di sekolah semakin sering ditemui, baik melalui informasi media cetak maupun televisi. Kekerasan tersebut dapat berupa pemukulan, memalak uang ataupun barang secara paksa, dan penghinaan. Perilaku tersebut biasa disebut bullying. Bullying kerap kali terjadi di lingkungan sekolah. Hal ini dapat menimbulkan efek bahaya baik secara fisik maupun emosional. Bullying, menurut Rigby (2001), adalah hasrat untuk menyakiti. Hasrat tersebut diperlihatkan dalam aksi yang menyebabkan seseorang menderita, dilakukan dengan perasaaan senang secara langsung oleh seseorang atau kelompok yang lebih kuat dan tidak bertanggung jawab.

Bullying adalah suatu tindakan kekerasan yang bertujuan untuk menyakiti, menghina, merendahkan, atau mengintimidasi orang lain. Tindakan ini dilakukan secara sengaja, bersifat nyata atau hampir tidak kentara, di hadapan seseorang atau di belakang seseorang, dan mudah diidentifikasi atau terselubung di balik persahabatan (Goodstein, 2013). Pada umumnya, bullying dilakukan oleh teman sebaya kepada temannya yang lebih rendah atau lebih lemah untuk mendapatkan suatu keuntungan bagi diri sendiri ataupun kepuasan tertentu. Perilaku bullying juga dikenal sebagai masalah sosial yang terutama terjadi di lingkungan sekolah. 
Penelitian yang dilakukan di 28 negara Eropa dan Amerika Utara tentang hubungan bullying, gejala fisik dan pychological di kalangan remaja dengan subjek sebanyak 123.227 siswa yang terdiri dari remaja usia 11, 13, dan 15 tahun menyatakan, siswa yang melaporkan telah menjadi korban bullying terhitung sangat besar. Bentuk penindasan yang dialami sangat bervariasi. Dari hasil penelitian, ditemukan bahwa pada setiap siswa yang diganggu pada setiap minggunya berakibat mengalami gangguan fisik seperti sakit kepala, sakit perut, sakit punggung, dan pusing, meningkat dari $1,83 \%$ menjadi $2,11 \%$. Sementara gejala psikologis yang dialami adalah temperamen buruk, merasakan perasaan negatif seperti gugup, kelelahan, ditinggalkan, kesepian, ketidakberdayaan, dan kesulitan tidur. Persentase meningkat dari 1,67\% meningkat menjadi 7,47\% (Due et al., 2005).

Prevalensi bullying di kalangan siswa sekolah di Ondo, Nigeria dengan sampel terdiri dari 600, menemukan hasil pengalaman dan manifestasi bullying menunjukkan bahwa kurang dari setengah dari 600 sampel (28\%) pernah mengalami bullying, sementara $42 \%$ lainnya pernah diintimidasi siswa lain (Owuamanam \& Makinwa, 2015).

Pada hasil asesemen yang dilakukan oleh peneliti terhadap perilaku bullying yang terjadi di salah salah satu Sekolah Menengah Pertama (SMP) Inklusi di Malang, salah satu siswa inklusi menyatakan dirinya menjadi korbang bullying dari siswa reguler, yakni mereka menarik uang secara paksa kepada dirinya. Berdasarkan hasil wawancara yang dilakukan dengan guru BK di SMP Muhammadiyah 2 Malang pada Oktober 2016, setiap tahunnya fenomena bullying memang bukan merupakan hal aneh yang terjadi di sekolah tersebut. Subjek yang sering menjadi korban bullying adalah siswa inklusi di SMP Muhammadiyah 2 Malang. Bullying biasanya dilakukan oleh siswa reguler di dalam ataupun di luar kelas. Perilaku bullying yang kerap terjadi adalah mencela dan mengejek, memalak, memukul, serta memberi penamaan kepada temannya. Tidak hanya pada siswa $\mathrm{ABK}$, bullying juga dilakukan pada sesama siswa reguler.

Berdasarkan data UNICEF tahun 2016, sebanyak 40\%-50\% remaja di Indonesia dalam rentang usia 13-15 tahun pernah mengalami tindakan cyber bullying. Fenomena bullying di Indonesia juga telah memasuki level yang mengkhawatirkan. Berdasarkan data Komisi Perlindungan Anak Indonesia (KPAI), sejak tahun 2011 sampai 2016 terjadi 253 kasus bullying, yang terdiri dari 122 anak yang menjadi korban dan 131 anak menjadi pelaku. Sedangkan dari data yang didapatkan oleh kementrian sosial hingga 2017, menunjukkan laporan 117 kasus bullying (KumparanSTYLE, 2017).

Remaja (adolescence) adalah individu yang berada pada masa perkembangan transisi antara masa anak-anak dan dewasa yang mencakup perubahan biologis, kognitif, dan sosio-emosional (Santrock, 2007). Pada perubahan sosialnya, individu dituntut untuk menampilkan perilaku yang dianggap pantas dan sesuai dengan orang-orang seusianya. Mereka akan memperluas lingkungan sosial di luar lingkungan keluarganya, yaitu lingkungan teman sebaya dan masyarakat. Menurut Hurlock (1998), hal tersulit dalam perubahan sosial yang dialami remaja adalah penyesuaian diri dengan meningkatnya pengaruh kelompok teman sebaya, perubahan perilaku sosial, pengelompokan sosial yang baru, nilai-nilai baru dalam persahabatan, dan nilai baru dalam penerimaan dan penolakan sosial. 
Permasalahan yang sering dihadapi oleh remaja berhubungan dengan penolakan teman sebaya adalah munculnya perilaku bullying. Remaja yang gagal dalam menjalin hubungan dengan dengan teman dan lingkungan sosialnya akan memandang dirinya negatif dan cendrung berpikir bahwa teman dan lingkungan tidak menerima dirinya. Hal tersebut yang kemudian menyebabkan remaja melakukan kenakalan. Remaja kurang memahami tentang dirinya sendiri dan tidak memiliki citra diri yang positif. Maka yang terjadi adalah mereka mudah terpangaruh oleh teman sebayanya. Pemahaman tentang diri sendiri disebut dengan konsep diri.

Konsep diri merupakan keadaan di mana seseorang mampu menilai dirinya secara fisik, psikis, sosial, emosional, aspirasi, dan prestasi. Konsep diri juga merupakan suatu cara untuk memprediksi tingkah laku seseorang. Seseorang yang memiliki konsep diri negatif akan memiliki perilaku yang negatif pula, seperti mudah menyerah dan selalu menyalahkan dirinya ketika mengalami kegagalan. Sebaliknya, ketika konsep diri yang dimiliki positif, maka berdampak pula pada perilaku positif, seperti terlihat lebih percaya diri dan selalu bersikap positif terhadap sesuatu.

Konsep diri berkembang berdasarkan pengalaman dari lingkungan, orang tua, teman sebaya, maupun diri sendiri. Perkembangan konsep diri berpengaruh terhadap perilakunya, yang menentukan bagaimana seseorang bersikap kepada diri sendiri dan orang lain. Remaja yang konsep dirinya positif mempunyai kemampuan interaksi sosial yang baik. Konsep diri dapat dikatakan sebagai komponen manusia dalam pengembangan kepribadiannya. Seseorang yang memiliki konsep diri positif akan mampu menjadi dirinya sendiri tanpa memperdulikan tanggapan orang lain tentang dirinya, mampu menerima kelebihan orang lain, memiliki penerimaan yang besar terhadap diri sendiri, serta lebih terbuka. Namun, jika konsep diri yang dimiliki negatif, individu akan memandang dirinya rendah dan kurang bisa menerima dirinya. Hal ini mengakibatkan individu akan bergantung pada penguatan dari luar, seperti menggantungkan evaluasi dirinya kepada orang lain. Hal ini menimbulkan kebutuhan akan pengakuan yang ditampilkan melalui perilaku yang dapat membuat individu terlihat berharga dan mampu diterima oleh lingkungannya. Didukung oleh penelitian yang dilakukan oleh Farisa (2010), hasil menunjukan bahwa terdapat hubungan antara konsep diri dengan kecenderungan berperilaku bullying. Semakin positif konsep diri diikuti dengan menurunnya kecenderungan berperilaku bullying.

Masa remaja juga sering disebut sebagai masa badai dan stres karena gejolak emosi yang dinamis. Pada masa remaja terjadi fluktuasi naik turunnya emosi dengan intensitas waktu lebih sering. Emosi pada remaja lebih mudah terprovokasi oleh lingkungan luarnya. Karenanya, sewaktu-waktu mereka dapat marah kepada orang tuanya dan memproyeksikan kemarahan kepada orang lain.

Pada masa remaja ini juga, individu lebih mampu menyadari siklus emosinya, seperti perasaan bersalah karena marah. Kesadaran tersebut dapat meningkatkan kemampuan remaja dalam mengatasi emosi dan terampil menampilkan emosinya kepada orang lain. Namun, ketika remaja tidak mampu mengelolah emosinya secara efektif, maka ia akan rentan mengalami depresi kemarahan dan kurang mampu meregulasi emosinya. Hal ini kemudian dapat memicu munculnya berbagai masalah, seperti kesulitan akademis, penyalahgunaan obat, gangguan makan, dan kenakalan remaja, yang salah satunya adalah perilaku bullying. 
Tim Field menyatakan bahwa salah satu karakteristik perilaku bullying di antaranya adalah tidak matang secara emosional. Bullying sangat erat kaitannya dengan kekerasan, penindasan, dan intimidasi yang seharusnya tidak terjadi jika seorang itu mampu mengendalikan dan mengelola emosinya, memahami diri, bersikap empati, dan tidak bersifat dendam dan iri hati kepada orang lain (Astuti, 2008).

Kematangan emosi adalah kemampuan remaja untuk mengekspresikan emosinya secara tepat dan wajar, memiliki kemandirian, konsekuensi, dan penerimaan diri yang tinggi. Individu dengan pengendalian diri yang baik mampu mengendalikan, mengarahkan, dan memahami emosinya untuk diarahkan kepada tindakan yang bersifat positif.

Kematangan diri secara emosional merujuk pada emosi yang menyangkut semua wilayah perilaku afektif, yang melibatkan aspek kognitif, biologis, dan sosial. Kematangan emosi merupakan proses di mana individu secara terus-menerus berusaha mencapai suatu tingkatan emosi yang sehat, baik secara intrafisik maupun interpersonal. Individu yang secara emosional telah matang dapat menentukan dengan tepat kapan dan sejauh mana dirinya perlu terlibat dalam suatu masalah sosial. Mereka juga dapat memberikan jalan keluar terhadap permasalahan.

Perilaku bullying disebabkan oleh pencapaian emosi yang kurang matang. Seorang remaja menjadi pelaku bullying karena belum mampu mengontrol dan mengekspresikan emosinya kepada cara-cara yang mampu diterima oleh kelompok. Didukung oleh penelitian yang telah dilakukan sebelumnya oleh Sari (2018), terdapat hubungan yang negatif antara kematangan emosi dengan perilaku bullying, dengan koefisien korelasi sebesar 0,974 yang menunjukkan bahwa kematangan emosi mempengaruhi perilaku bullying pada remaja sebesar 97,4\%. Dapat diartikan bahwa kematangan emosi yang rendah akan dikuti oleh perilaku bullying yang tinggi.

Anderson dan Bushman (2002), juga mengungkapkan bahwa faktor-faktor yang mempengaruhi terjadinya perilaku bullying adalah faktor personal dan situasional. Faktor personal adalah karakteristik yang ada pada diri seseorang, termasuk kepribadian, sikap, dan bawaan genetik. Faktor personal inilah yang menjelaskan bahwa pada karakteristik seseorang, terdapat kepribadian yang mempengaruhi konsep diri dan kematangan emosi seseorang, sehingga mempengaruhi pergaulan seseorang dalam kehidupannya sehari-hari. Perilaku ini kemudian dapat memicu timbulnya bullying (Saifullah, 2010).

Berdasarkan data dan fenomena yang telah diuraikan di atas, maka konsep diri merupakan keadaan di mana seseorang mampu menilai dirinya secara fisik, psikis, sosial, emosional, aspirasi, dan prestasi. Kematangan emosi adalah kemampuan remaja untuk mengekspresikan emosinya secara tepat dan wajar, memiliki kemandirian, konsekuensi, dan penerimaan diri yang tinggi. Sedangkan perilaku bullying adalah tindak kekerasan yang dilakukan dengan tujuan untuk menyakiti, menghina, merendahkan, atau mengintimidasi orang lain. Peneliti tertarik untuk melakukan penelitian tentang seberapa besar hubungan konsep diri dan kematangan emosi dengan perilaku bullying pada remaja.

Secara umum, penelitian ini bertujuan untuk mengetahui, menggali, mengkaji, dan mengorganisasikan informasi teoritik dan empirik mengenai hubungan konsep 
diri dan kematangan emosi dengan perilaku bullying pada remaja. Adapun manfaat penelitian secara teoritis adalah memberikan informasi mengenai hubungan konsep diri dan kematangan emosi dengan perilaku bullying pada remaja.. Sedangkan manfaat secara praktis adalah memberikan informasi orang tua, lembaga, atau pihak yang terkait mengenai perilaku bullying pada remaja.

\section{METODE PENELITIAN}

Rancangan penelitian yang digunakan adalah penelitian kuantitatif non eksperimen, yakni penelitian dengan data kuantitatif atau data yang dapat dikuantitatifkan dan diolah dengan menggunakan teknik statistik.

Desain penelitian yang digunakan penelitian ini adalah desain korelasi parsial. Korelasi parsial adalah suatu teknik statistika yang digunakan untuk mempelajari hubungan murni antara sebuah variabel bebas $\left(\mathrm{X}_{1}\right)$ dengan variabel terikat $(\mathrm{Y})$ dengan mengendalikan atau mengontrol variabel-variabel bebas yang lain $\left(\mathrm{X}_{2}\right)$ yang diduga mempengaruhi hubungan $X_{1}$ dengan $Y$ (Telussa, Persulessy, \& Leleury, 2013).

Subjek dalam penelitian ini adalah remaja di SMP Negeri 1 Plampang. Adapun pengambilan sampel dalam penelitian ini dilakukan dengan sampling kuota. Sampling kuota adalah sampel yang diambil berasal dari populasi yang mempunyai ciri-ciri tertentu sampai jumlah (kuota) yang diinginkan oleh peneliti terpenuhi (Sugiyono, 2016). Subjek dalam penelitian ini adalah individu dalam periode masa remaja awal. Kriteria adalah subjek siswa sekolah menengah pertama (SMP) atau sederajat yang berusia 12-15 tahun dengan jenis kelamin laki-laki atau perempuan.

Populasi di SMP Negeri 1 Plampang berjumlah 262 siswa. Peneliti menggunakan ukuran sampel dengan tingkat kesalahan 5\% menjadi 150 sampel, yang dikembangkan berdasarkan tabel Isaac dan Michael (Sugiyono, 2016).

Bullying adalah suatu perilaku yang menjurus pada tindakan kekerasan yang bertujuan untuk menyakiti seseorang yang lebih lemah. Perilaku bullying diukur dengan menggunakan skala perilaku bullying yang disusun berdasarkan aspek perilaku bullying, yaitu 1) bullying fisik yang ditandai dengan memukul, menendang, mencakar dan lain-lain yang berbentuk kekerasan fisik, 2) bullying verbal, perilaku kekerasan yang berbentuk verbal seperti mengejek ataupun menghina, dan 3) bullying psikologis, kekerasan yang berbentuk teror, mencibir, dan memandang rendah orang lain. Skala perilaku bullying memiliki sebaran nilai validitas antara 0,397-0,599 serta reliabilitas 0,873 , terdiri dari 34 item dalam bentuk skala likert berupa pernyataan berbentuk kalimat positif dan negatif dengan pilihan jawaban "SS" (sangat setuju) = 4, “S” (setuju) = 3, TS “(tidak setuju)" = 2, “STS" (sangat tidak setuju) = 1 .

Konsep diri adalah gambaran tentang diri seseorang yang menyangkut karakteristik dirinya. Konsep diri biasanya terbentuk dari lingkungan sekitarnya dan banyak dipengaruhi oleh keluarga (primer). Ketika seseorang telah banyak dipengaruhi oleh lingkungan luar, konsep diri pun mulai berkembang. Konsep diri diukur dengan meggunakan skala konsep diri yang disususn berdasarkan aspek konsep diri, yaitu fisiologis, psikologis, psikososiologis, psiko-spiritual, psikoetika, dan moral. Skala konsep diri terdiri dari 28 item dengan indeks validitas antara 0,8950,902 serta reliabilitas 0,882. Skala konsep diri berbentuk skala likert, berupa 
pernyataan berbentuk kalimat positif dan negatif dengan pilihan jawaban, "SS" (sangat setuju $=4$, “S" (setuju) = 3, TS "(tidak setuju)" = 2, "STS" (

Kematangan emosi adalah keadaan perasaan seseorang di mana seseorang mampu mengeskpresikan emosinya dalam bentuk yang positif. Sehingga dalam bertingkah laku, seseorang dapat menentukan perilakunya di dalam lingkungan serta konsisten meskipun suasana hati berubah-ubah. Kematangan emosi diukur dengan menggunakan skala kematangan emosi yang disusun berdasarkan aspek kematangan emosi, yaitu dapat menerima baik keadaan dirinya sendiri maupun orang lain seperti apa adanya secara objektif, tidak bersifat impulsive, dapat mengontrol diri dan ekspresi emosinya secara baik, berpikir objektif, dan mempunyai tanggung jawab yang baik. Skala kematangan emosi ini terdiri dari 29 item dengan sebaran nilai validitas antara 0,739-0,798 serta nilai reliabilitas 0,762. Skala kematangan emosi berbentuk skala likert, berupa pernyataan berbentuk kalimat positif dan negatif dengan pilihan jawaban, "SS" $($ sangat setuju $)=4$, “S” (setuju $)=3$, TS “(tidak setuju)" = 2, “STS" (sangat tidak setuju) = 1.

Penelitian ini memiliki tiga prosedur utama. Pertama, tahap perencanaan. Tahap ini dimulai dari merumuskan permasalahan, mencari kajian pustaka dari permasalahan yang diangkat, menyusun kerangka berpikir hingga hipotesis, menentukan sampel, menentukan metode analisis data penelitian, dan melakukan uji coba. Peneliti juga menyusun ataupun menggunakan alat ukur yang sudah ada berdasarkan aspek dalam variabel, kemudian melakukan pengambilan data kepada subjek yang sudah ditentukan.

Tahapan berikutnya yaitu tahap penelitian. Pada tahap ini, peneliti mulai mengumpulkan data dengan cara menyebarkan skala pada subjek yang telah ditentukan sebanyak 150 orang. Peneliti memberikan tiga skala, yaitu skala bullying, konsep diri, dan kematangan emosi.

Terakhir, tahap analisis, yaitu menganalisis hasil yang telah didapatkan dari penyebaran tiga skala kepada 150 subjek. Data-data yang telah diperoleh di-input dan diolah dengan menggunakan program perhitungan statistik Statistical Package For Social Sciense (SPSS) 21. Peneliti akan menginterpretasikan hasil yang telah didapatkan dan mengaitkan dengan teori berdasarkan hipotesis. Dalam penelitian ini, analisis data yang digunakan adalah korelasi parsial. Korelasi parsial digunakan menentukan hubungan konsep diri dengan perilaku bullying jika kematangan emosi dikendalikan. Analisis korelasi parsial ini nantinya akan dilakukan uji normalitas, uji linearitas, dan uji hipotesis. Tahapan berikutnya adalah tahap terakhir. Tahap terakhir yaitu tahap penulisan laporan penelitian. Tahap ini dilakukan setelah penelitian selesai dilakukan.

\section{HASIL PENELITIAN}

Penelitian ini dilakukan di SMP Negeri 1 Plampang pada siswa kelas VII dan VIII. Berdasarkan hasil penelitian yang telah dilakukan, didapatkan hasil sebagai berikut.

Tabel 1. Deskriptif Subjek (N=150)

\begin{tabular}{lll}
\hline Kategori & Frekuensi & Presentase \\
\hline Jenis Kelamin & & \\
\hline
\end{tabular}




\begin{tabular}{lcc}
\hline Laki-laki & 65 & $43,3 \%$ \\
Perempuan & 85 & $56,7 \%$ \\
\hline Usia & & \\
12 Tahun & 17 & $11,3 \%$ \\
13 Tahun & 52 & $34,7 \%$ \\
14 Tahun & 57 & $38 \%$ \\
15 Tahun & 24 & $16 \%$ \\
\hline
\end{tabular}

Berdasarkan tabel 1, diketahui bahwa dari 150 subjek terdapat jumlah subjek dengan jenis kelamin laki-laki sebanyak 62 orang (43,3\%) dan subjek perempuan sebanyak 85 orang (56,7\%). Kemudian dilihat dari usia subjek, dari 150 orang subjek penelitian, subjek yang berada pada kategori usia 12 tahun sebanyak 17 orang (11,3\%), usia 13 tahun sebanyak 52 orang $(34,7 \%)$, usia 14 tahun sebanyak 57 orang (38\%), dan usia 15 tahun sebanyak 24 orang (16\%). Penelitian ini dilakukan pada siswa SMP Negeri 1 Plampang, kecamatang Plampang, Kabupaten Sumbawa, Nusa Tenggara Barat.

Tabel 2. Deskripsi Variabel Penelitian (N=150)

\begin{tabular}{lccc}
\hline \multicolumn{1}{c}{ Variabel } & Range & Mean & Standar Deviasi \\
\hline Konsep Diri & $71-103$ & 86.66 & 6.736 \\
Kematangan Emosi & $68-106$ & 86.51 & 8.032 \\
Perilaku Bullying & $34-86$ & 44.91 & 9.789 \\
\hline
\end{tabular}

Berdasarkan tabel 2, diketahui bahwa variabel konsep diri $\left(X_{1}\right)$ memiliki nilai minimum dan maksimum sebesar 71-103 dengan mean=86,66 dan standar deviasi $=$ 6,736. kemudian pada variabel kematangan emosi $\left(X_{2}\right)$ memiliki nilai minimum dan maksimum sebesar 68-108 dengan mean $=86,51$ dan standar deviasi $=8,032$. Pada variabel perilaku, bullying memiliki nilai minimum dan maksimum sebesar 34-86 dengan mean $=44.911$ dan standar deviasi $=9.789$.

Sebelum melakukan uji hipotesis, diperlukan uji asumsi yaitu uji normalitas data yang bertujuan untuk menguji apakah data berdistribusi normal atau tidak. pengujian data menggunakan one sampel kolmogorov test. Jika data berdistribusi normal, maka digunakan statistik parametrik. Namun, jika data tidak berdistribusi normal, maka digunakan statistik non parametrik. Data dinyatakan normal jika nilai $p>0,05$.

Berdasarkan hasil uji normalitas dengan menggunakan one sampel kolmogorov, diketahui bahwa variabel konsep diri $\left(X_{1}\right)$ berdisitribusi normal $(p=0,117>0,05)$, variabel kematangan emosi $\left(X_{2}\right)$ juga dinyatakan berdistribusi normal $(p=0,287>0,05)$. Kemudian variabel perilaku bullying $(\mathrm{Y})$ dinyatakan berdistribusi tidak normal $(p=$ $0,001<0,05$. Oleh karena itu, dilakukan uji hipotesis dengan menggunakan uji Kendall's tau_b. Selanjutnya, untuk mengetahui ada tidaknya hubungan antara konsep diri dan kematangan emosi dengan perilaku bullying pada remaja, peneliti melakukan analisis 
ADOLESCENCE, BEHAVIOR, BULLYING, EMOTIONAL MATURITY, SELF CONCEPT

korelasi. Di mana analisis yang dilakukan adalah bivariate correlation. Berikut adalah hasil analisis korelasi yang telah dilakukan. 


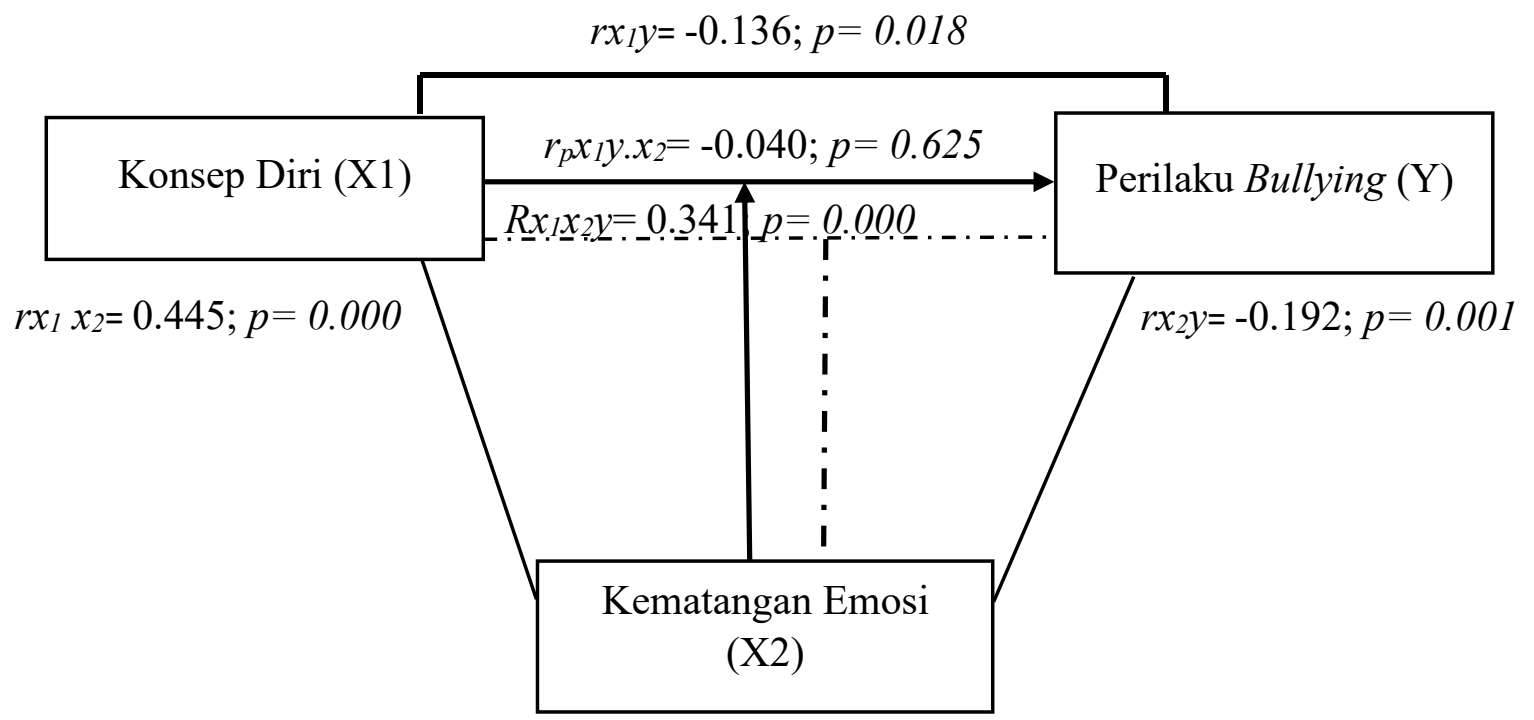

Gambar 1. Gambar relasi antar variabel

Berdasarkan gambar 1, diketahui bahwa hasil uji bivariate correlation menunjukkan bahwa ada hubungan signifikan antara variabel konsep diri $\left(X_{1}\right)$ dan variabel kematangan emosi $\left(\mathrm{X}_{2}\right)$ dengan variabel perilaku bullying $(\mathrm{Y})$ pada remaja $(R=$ $0,341 ; p=0,000)$. Selain itu, ada hubungan signifikan antara variabel konsep diri $\left(\mathrm{X}_{1}\right)$ dengan variabel perilaku bullying (Y) pada remaja $(r=-0,136 ; p=0,018)$. Terdapat pula hubungan signifikan antara variabel kematangan emosi $\left(X_{2}\right)$ dengan variabel perilaku bullying $(Y)(r=-0,192 ; p=0,001)$. Selanjutnya, dapat diketahui hubungan antara kedua variavel $(X)$, yaitu ada hubungan yang signifikan antara variabel konsep diri $\left(X_{1}\right)$ dan variabel kematangan emosi $\left(\mathrm{X}_{2}\right)(r=0,455 ; p=0,000)$.

Kemudian pada hasil uji partial correlation, hasil menunjukkan tidak ada hubungan antara variabel konsep diri $\left(\mathrm{X}_{1}\right)$ dan variabel perilaku bullying $(\mathrm{Y})$ dengan variabel kematangan emosi $\left(\mathrm{X}_{2}\right)$ dikendalikan $(r=-0,040 ; p=0,625)$.

\section{DISKUSI}

Berdasarkan hasil analisis dan uji hipotesis yang telah dilakukan, antara variabel konsep diri, kematangan emosi, dan perilaku bullying dengan menggunakan uji bivariate correlation dan partial correlation, menghasilkan bahwa konsep diri, kematangan emosi, dan perilaku bullying secara simultan atau bersama-sama berhubungan dengan perilaku bullying. Hal ini berarti bahwa konsep diri dan kematangan emosi dapat memprediksi perilaku bullying pada remaja.

Sedangkan konsep diri dan perilaku bullying dengan kematangan emosi dikendalikan tidak memiliki hubungan. Hal tersebut terjadi karena hubungan yang diuji secara simultan belum merupakan hasil murni yang dapat memprediksi hubungan konsep diri dengan perilaku bullying pada remaja. Masih terdapat hubungan konsep diri dan kematangan emosi yang dapat mengganggu hubungan murni antara konsep diri dengan perilaku bullying. Sehingga, hubungan yang terjadi pada konsep diri dengan perilaku bullying remaja dapat dikatakan sebagai hasil 
hubungan murni antara konsep diri dengan perilaku bullying. Tidak terdapat gangguan dari variabel ataupun faktor lain yang dapat mempengaruhi hubungan konsep diri dengan perilaku bullying remaja. Konsep diri dan perilaku bullying remaja tidak ada hubungan dengan kematangan emosi yang dikendalikan. Hal ini menunjukkan bahwa konsep diri bukan merupakan salah satu penyebab perilaku bullying pada remaja.

Penelitian ini membuktikan bahwa kematangan emosi memiliki hubungan yang signifikan dengan perilaku bullying remaja. Hal ini sesuai dengan penelitian sebelumnya oleh Singh (2016), yang menyatakan bahwa seseorang yang tidak memiliki kematangan emosi memiliki tingkat agresivitas yang tinggi. Kematangan emosi adalah kemampuan individu dalam mengontrol dan mengendalikan emosinya. Ia terus-menerus berusaha mencapai keadaan emosi yang lebih baik secara intrafisk maupun interpersonal. Individu yang telah mencapai kematanagn emosi biasanya ditandai dengan adanya kemampuan mengontrol emosi secara baik, mampu berpikir realistis, memahami diri sendiri, dan mampu menempatkan emosi pada waktu dan tempat yang tepat. Remaja yang matang emosinya mampu mempertahankan dan memahami emosi dirinya untuk diarahkan pada kepada tindakan-tindakan yang positif. Mereka menilai situasi secara kritis terlebih dahulu sebelum bertindak secara emosional dan tidak lagi bertindak tanpa berpikir sebelumnya. Selain itu, mereka akan menghindari perilaku-perilaku negatif yang membahayakan orang lain, seperti memukul, mengejek, mencaci maki, ataupun memfitnah orang lain.

Konsep diri juga memiliki hubungan yang signifikan dengan perilaku bullying remaja. Hal tersebut sesuai dengan penelitian yang dilakukan oleh Fanti dan Henrich (2015), yang menyatakan bahwa semakin rendah konsep diri seseorang, maka menyebabkan agresi yang lebih tinggi sebagai upaya untuk meningkatkan harga diri. Pendapat lain juga dikemukakan oleh Blakely-McClure dan Ostrov (2016), yang menyatakan bahwa adanya hubungan antara konsep diri dengan perilaku agresi pada remaja. Individu yang merasa tidak nyaman dengan kemampuan ataupun penampilan fisiknya akan berperilaku agresi sebagai cara untuk mendapatkan status di lingkungannya. Konsep diri memainkan peran utama dalam perilaku manusia. Konsep diri muncul pada masa anak-anak melalui interaksi dengan lingkungan. Konsep diri adalah persepsi individu tentang dirinya yang berkaitan dengan lingkungan dan orang lain. Sikap atau respon orang tua merupakan informasi bagi individu untuk menilai siapa dirinya, sehingga ia akan menilai dirinya berdasarkan apa yang didapatnya dari lingkungan. Jika lingkungan memberikan sikap yang positif, maka individu akan merasa bahwa dirinya berharga sehingga muncul konsep diri positif. Rogers membedakan konsep diri menjadi dua, yaitu konsep diri positif dan negatif. Individu dengan konsep diri positif akan menerima keberadaan dirinya. Ia merasa dirinya berharga, disukai, dan diterima. Individu dengan konsep diri positif akan menjadi dirinya sendiri tanpa memedulikan tanggapan orang lain tentang dirinya, menerima kelebihan orang lain, memiliki penerimaan yang besar terhadap diri, serta lebih terbuka. Sebaliknya, individu dengan konsep diri negatif akan memandang dirinya rendah dan kurang bisa menerima dirinya. Ia lebih tergantung dan terpengaruh oleh lingkungannya, sehingga merasa bahwa kekuatan yang lebih besar adalah bersumber di luar dirinya. Ketika individu lebih bergantung pada 
penguatan dari luar, ia akan menggantungkan evaluasi dirinya kepada orang lain. Pada akhirnya, timbul kebutuhan akan pengakuan yang ditampilkan melalui perilaku yang dapat membuat individu terlihat berharga dan mampu diterima oleh lingkungannya

Hubungan antara konsep diri dengan perilaku bullying adalah sebesar $r_{1}=-$ 0,136, sedangkan nilai hubungan kematangan emosi dengan perilaku bullying sebesar $\mathrm{r}_{2}=-0,192$. Hal ini menunjukkan bahwa kematangan emosi memberikan kontribusi yang lebih banyak dibandingkan dengan konsep diri dalam hal menentukan tinggi redahnya perilaku bullying remaja. Nilai hubungan konsep diri dengan kematangan emosi sebesar $r=0,445$. Artinya, konsep diri dan kematangan emsoi merupakan faktor internal yang dimiliki oleh setiap individu dan kedua faktor internal tersebut saling memiliki hubungan. Konsep diri dan kematangan emosi adalah suatu komposisi. Konsep diri ada dalam kematangan emosi dan kematangan emosi ada dalam konsep diri. Individu yang mampu memahami dan menempatkan diri secara baik dalam lingkungan akan memiliki kematangan emosi yang baik, sehingga dapat membedakan hal-hal positif dan negatif sebelum bertindak.

Konsep diri, secara parsial, memiliki hubungan yang lemah dengan perilaku bullying. Individu dengan konsep diri yang negatif kemungkinan akan berkonflik dengan kematangan emosi. Konsep diri negatif yang tidak terkontrol akan membentuk suatu perilaku yang tidak rasional. Kematangan emosi yang tidak mampu mengendalikan konsep diri akan membelokkan arah hubungan kematangan emosi dengan perilaku bullying.

\section{SIMPULAN DAN IMPLIKASI}

Berdasarkan hasil penelitian, dapat disimpulkan bahwa tidak ada hubungan antara konsep diri dan perilaku bullying dengan kematangan emosi yang dikendalikan. Dari hasil tersebut, hipotesis peneliti tidak diterima. Hal ini menunjukkan bahwa konsep diri bukan merupakan salah satu penyebab perilaku bullying pada remaja dan bukan sebuah faktor yang dapat meningkatkan atau menurunkan perilaku bullying. Implikasi dari penelitian ini untuk remaja adalah agar mampu menyeimbangkan antara konsep diri dengan kematangan emosinya agar mampu memposisikan dirinya secara tepat dalam lingkungan, menerima setiap apapun keadaan diri, menghargai orang lain, mau menerima saran, dan membangun sosial yang baik dengan sesama. Matangnya konsep diri dan kematangan emosi mampu membentuk perilaku positif. Bagi peneliti selanjutnya yang tertarik melakukan penelitian dengan tema-tema serupa, disarankan untuk lebih mengembangkan lagi dengan variabel bebas lainnya.

\section{REFERENSI}

Anderson, C. A., \& Bushman, B. J. (2002). Human aggression. Annual Review of Psychology, 27-51. Astuti, ponny retno. (2008). Meredam bullying. 3 cara efektif mengatasi kekerasan pada anak. Jakarta: Kompas Gramedia.

Berzonsky, M. . (1981). Adolescent development. New York: Macmillan Publishing.

Blakely-McClure, S. J., \& Ostrov, J. M. (2016). Relational aggression, victimization and selfconcept: testing pathways from middle childhood to adolescence. Journal of Youth and Adolescence, 45(2), 376-390.

Daniel, G. (1999). Kecerdasan emosional untuk mencapai puncak prestasi. Jakarta: PT Gramedia 
Pustaka Utama.

Dariyo, A. (2007). Psikologi perkembangan anak usia tiga tahun pertama (psikologi atitama). Bandung: Refika Aditama.

Due, P., Holstein, B. E., Lynch, J., Diderichsen, F., Gabhain, S. N., Scheidt, P., \& Currie, C. (2005). Bullying and symptoms among school-aged children: International comparative cross sectional study in 28 countries. European Journal of Public Health, 15(2), 128-132.

Education.com. (2012). Bullying at school and online. Education.com.

Fanti, K. A., \& Henrich, C. C. (2015). Effects of self-esteem and narcissism on bullying and victimization during early adolescence. Journal of Early Adolescence, 35(1), 5-29.

Goodstein, P. K. (2013). How to stop bullying in classrooms and school. New York: Routledge.

Guswani, A., \& Kawuryan, F. (2011). Perilaku agresi pada mahasiswa ditinjau dari kematangan emosi. Jurnal Psikologi Pitutur, 1(2), 86-92.

Hurlock, B. (1998). Perkembangan Anak. Jakarta: Erlangga.

Jahja, Y. (2011). Psikologi perkembangan. Jakarta: Prenadamedia Group.

Kail, Robert V \& Cavanaugh, J. C. (2015). Essentials of human development: a life-span view. Boston: Cengage Learning.

KumparanSTYLE. (2017). Kasus bullying meningkat, pelaku didominasi oleh remaja. Retrieved April 19, 2017, from https://kumparan.com/@kumparanstyle/kasus-bullying-meningkatpelaku-didominasi-oleh-remaja

Muzdalifah, F., \& Afriyanto, H. B. (2014). Pengaruh konsep diri terhadap perilaku bullying pada mahasiswa di universitas X. Jurnal Penelitian dan Pengukuran Psikologi, 3(2), 59-64.

Owuamanam, D. O., \& Makinwa, V. I. (2015). Prevalence of bullying among secondary school students in Ondo State, Nigeria. European Scientific Journal, 11(20), 1857-7881.

Paul, L. (2003). Bullying at school - school environment (CA Dept of Education).

Rakhmat, J. (2007). Psikologi komunikasi (Ed. Revisi). Bandung: PT Remaja Rosda Karya.

Rigby, K. (2001). Stop the bullying: A handbook for schools. Australian: National Library of Australia Cataloguing

Saifullah, F. (2010). Hubungan antara konsep diri dengan bullying pada siswa-siswi SMP (SMP Negeri 16 Samarinda). Jurnal Psikologi, 4(2), 200-213.

Santrock, J. . (2007). Life-span development: Perkembangan masa hidup, jilid 1, edisi ketigabelas. Jakarta: Erlangga.

Sari, S. . (2018). Hubungan kematangan emosi dengan kecendrungan perilaku bullying pada remaja akhir di SMA XI Yogyakarta. Skripsi, Universitas Isalam Indonesia, Yogyakarta.

Sejiwa. (2008). Bullying: Mengatasi kekerasan di sekolah dan lingkungan sekitar anak. Jakarta: Grasindo.

Singh, M. (2016). A study of aggression among adolescents in relation to their emotional maturity. Scholarly Research Journal for Interdisciplinary Studies (4), 3091-309727.

Sugiyono. (2016). Metode penelitian kuantitatif, kualitatif, dan RED. Bandung: Alfabeta.

Telussa, A. D. E. M., Persulessy, E. R., \& Leleury, Z. A. (2013). Penerapan analisis korelasi parsial untuk menentukan hubungan pelaksanaan fungsi manajemen kepegawaian dengan efektivitas kerja pegawai ( Studi Kasus pada Badan Pendapatan, Pengelolaan Keuangan dan Aset Daerah Provinsi Maluku ). Jurnal Barekeng, 7(1), 15-18.

Walgito, B. (2002). Pengantar psikologi umum. Yogyakarta: Andi Offeset. 